Ann. Biol. anim. Bioch. Biophys., 1979, 19 (5), 1619-1623.

\title{
Fertilization and embryo survival rates in control and progesterone or HCG treated heifers
}

\author{
par J. M. SREENAN, M. G. DISKIN, Mary MURPHY \\ The Agriculfural Institute, Belclare, \\ Tuam, Galway, Ireland.
}

\begin{abstract}
Summary. A total of 98 heifers were used in a study of fertilization and embryonic mortality rates.

Fertilization rate recorded at day 4 was 90 p. 100 . Embryo survival at day 42 was 52 p. 100 . Progesterone supplementation did not affect circulating progesterone level and slightly increased embryo survival rate. HCG administration induced accessory corpus luteum formation, increased circulating progesterone level and slightly increased embryo survival. The increases in embryo survival following progesterone or HCG were not significant $(P>0.10)$.
\end{abstract}

\section{Introduction.}

Embryonic mortality is a major cause of economic loss in cattle breeding enterprises. Fertilization rate of about 80-100 p. 100 (Laing, 1949 ; Kidder et al., 1954 and Spitzer ef al., 1978) and calving rates following a single insemination of 50-60 p. 100 (Boyd and Reed, 1961 ; Sreenan and Mulvehill, 1975 ; Roche et al., 1977 and Wishart ef al., 1977) suggest an embryonic mortality rate of about 30 p. 100 . While the relationship between the embryo, the uterus and the $\mathrm{CL}$ (Corpus Luteum) remains undefined, inadequate progesterone level has been suggested many times as a possible cause of at least some proportion of this loss (Boyd, 1965). While the differences have been non significant, yet there has been a trend towards improved embryo survival following progesterone supplementation in some studies (Wiltbank ef al., 1956 ; Johnson ef al., 1958).

The present study was carried out to determine the fertilization and embryo survival rates following a single insemination and to determine the effect of exogenous progesterone or HCG administration on CL weight and number, circulating progesterone level and embryonic survival.

\section{Material and methods.}

A total of 98 Hereford cross beef heifers were used. These heifers were synchronized with 9-day intravaginal progesterone sponges and following sponge removal 
were checked frequently for the occurrence of standing œstrus. At œstrus heifers were randomly allotted to a fertilization group or to a control or treatment group for embryo survival study.

Progesterone or HCG treatment group. - Progesterone $(100 \mathrm{mgm})$ or HCG $(1,500$ i.u. $)$ was injected i.m. daily from Day 10 to 20 inclusive (Day of œstrus = day 0 ).

Control group. - Sterile distilled water $(5 \mathrm{ml})$ was injected i.m. daily from Day 10 to 20 inclusive.

Artificial insemination. - Each heifer was inseminated towards the end of standing oestrus with frozen-thawed semen (approximately $30 \times 10^{6}$ spermatazoa per straw) from the same bull.

Fertilization rate was assessed by in vivo flushing and ovum recovery on day 4. Embryo survival was assessed by slaughter at day 42 and survival rate was based on the recovery of viable fetuses only. Progesterone levels were determined by radioimmunoassay (Gosling, Parker and Fottrell, 1975).

\section{Results and discussion.}

The fertilization and subsequent pregnancy rates in control and treated heifers are shown in table 1.

TABLE 1

Fertilization rate and the effect of progesterone or HCG on pregnancy rates

\begin{tabular}{ccccc}
\hline \multirow{2}{*}{$\begin{array}{c}\text { Replicate } \\
\text { No. }\end{array}$} & $\begin{array}{c}\text { Fertilization } \\
\text { rate }\end{array}$ & \multicolumn{3}{c}{ Pregnancy rate - Day 42 } \\
\cline { 3 - 5 } & $2 / 2$ & Control & + progesterone & + HCG \\
\hline & $3 / 3$ & $2 / 3$ & $2 / 3$ & $3 / 3$ \\
2 & $4 / 5$ & $0 / 2$ & $2 / 3$ & $1 / 3$ \\
3 & $2 / 2$ & $3 / 5$ & $2 / 3$ & $3 / 7$ \\
4 & $1 / 1$ & $1 / 3$ & $5 / 5$ & $2 / 2$ \\
5 & $7 / 8$ & $3 / 4$ & $3 / 5$ & $3 / 5$ \\
6 & $19 / 21$ & $4 / 8$ & $4 / 7$ & $5 / 6$ \\
\hline Total $\ldots \ldots \ldots \ldots \ldots$ & 90 & $13 / 25$ & $18 / 26$ & 65 \\
p. $100 \ldots \ldots \ldots \ldots$ & 52 & 69 & \\
\hline
\end{tabular}

The overall fertilization rate was 90 p. 100 . The pregnancy rates in the progesterone and HCG groups were higher than the control group but the difference was non significant $(p>0.10)$.

The effect of progesterone supplementation and HCG administration on circulating progesterone levels is shown in figure 1.

While the mean progesterone levels in the progesterone supplemented group were higher than the control group the differences were not significant $(P>0.10)$. There was however a significant increase in progesterone level in the HCG treated 


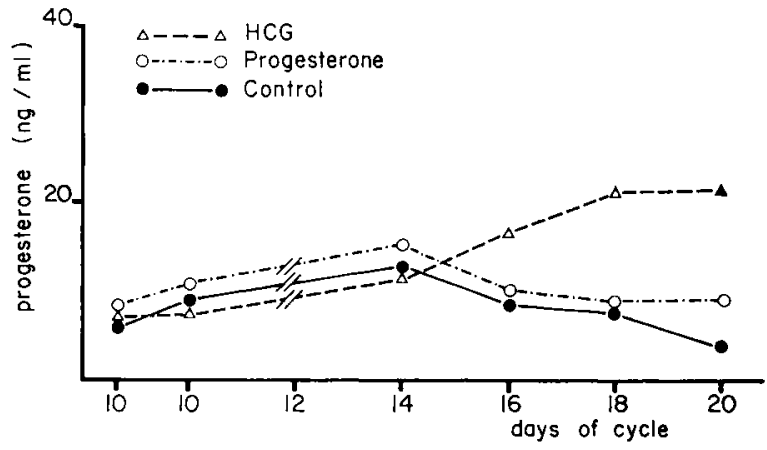

FIG. 1. - Effect of progesterone supplementation and HCG administration on circulating progesterone levels.

group from day 15 onwards $(P<0.05)$. This increased progesterone level resulted mainly from an increase in the number of supplementary CLs formed as a result of the HCG treatment (table 2). The number of $C L$ s and therefore the weight of luteal tissue per heifer was significantly increased in the HCG group $(P<0.01)$. There was no significant difference between the mean $C L$ tissue weight of the control or progesterone groups $(P>0.10)$.

TABLE 2

Effect of progesterone or HCG on Corpus luteum $(\mathrm{CL})$ number and weight in pregnant heifers

\begin{tabular}{|c|c|c|c|}
\hline & \multicolumn{3}{|c|}{ Treatment } \\
\hline & Control & + Progesterone & $+\mathrm{HCG}$ \\
\hline 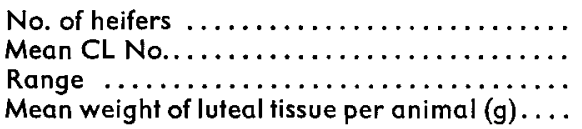 & $\begin{array}{c}13 \\
1.08 \\
1-2 \\
5.1 \pm 0.4\end{array}$ & $\begin{array}{c}17 \\
1.00 \\
1 \\
4.5 \pm 0.3\end{array}$ & $\begin{array}{c}17 \\
2.17 \\
1-4 \\
8.7 \pm 0.7\end{array}$ \\
\hline
\end{tabular}

Data on the effect of accessory CLs on embryo survival (HCG group) is given in table 3.

TABLE 3

Effect of Corpus luteum number on embryo survival

\begin{tabular}{lcc}
\hline & \multicolumn{2}{c}{$C L$ number } \\
\cline { 2 - 3 } & 1 & $2-4$ \\
\hline No. of heifers $\ldots \ldots \ldots \ldots \ldots$ & 8 & 14 \\
No. pregnant $\ldots \ldots \ldots \ldots \ldots$ & 5 & 12 \\
p. $100 \ldots \ldots \ldots \ldots \ldots \ldots$ & 62,5 & 85.7 \\
\hline
\end{tabular}


While the numbers involved are very limited indeed there was no obvious trend.

In the assessment of fertilization rate, recovery rate of ova was 82 p. 100, of which 90 p. 100 were fertilized. These recovery and fertilization rates are in agreement with other studies (Laing, 1949 ; Kidder et al., 1954 ; Spilzer ef al., 1978). The pregnancy rate of 52 p. 100 in the control group, suggests an embryo mortality rate of 38 p. 100 within this study and while this is slightly higher than some estimates (Hawk ef al., 1955 ; Erb and Holtz, 1958) it is in agreement with Laing (1949) and with the many reports in the literature showing calving rates of 50-60 p. 100 after a single insemination as shown earlier.

The progesterone supplemented group had a higher number of viable fetuses at slaughter but there was not a statistical difference. Similar, but non significant increases in pregnancy rate in progesterone supplemented animals have been reported (Wiltbank ef al., 1956 ; Johnson ef al., 1958). The relationship between circulating progesterone level and pregnancy rate is not clear. Henricks et al. (1971) and Erb ef al. (1976) have reported higher progesterone levels in pregnant heifers as early as days 6-9 after breeding when compared with bred but non-pregnant heifers. However, the data of Spitzer et al. (1978) did not indicate any definite relationship between pregnancy rate and progesterone level.

The administration of HCG also resulted in a higher (non-significant) pregnancy rate. HCG induced accessory CLs in 12 of 17 (70 p. 100) of the heifers that were pregnant and this in agreement with the report of Wiltbank ef al. (1961) who reported accessory CL formation in 67 p. 100 of HCG treated heifers that became pregnant. The formation of accessory CLs significantly increased the level of circulating progesterone (fig. 1) but the numbers of heifers were too small to determine the effect of accessory CL formation on embryonic survival. It is clear from the HCG group that levels of circulating progesterone as high as $40 \mathrm{ng} / \mathrm{ml}$ in individual cases did not cause embryonic death but it is also clear that animals with normal luteal progesterone levels failed to maintain pregnancy.

Further study is required involving large numbers of animals on the timing and dose levels of progesterone supplementation or HCG administration to determine whether the increased pregnancy rates recorded in this and other studies are real and also to determine the relationship between the embryo and $\mathrm{CL}$.

EEC Seminar on « Ovarian stimulation and egg quality in mommals », Luynes, France, ocfobre 1978.

Résumé. Les taux de fécondation et de mortalité embryonnaire ont été comparés chez 98 génisses synchronisées. Le taux de fécondation a été estimé au 4 e jour à 90 p. 100 par examen des œufs récupérés par perfusion in vivo. Le taux de survie embryonnaire à 42 jours est seulement de 52 p. 100 . L'injection de $100 \mathrm{mg} /$ jour de progestérone du $10^{\mathrm{e}}$ au $20^{\mathrm{e}}$ jour améliore légèrement le taux de survie embryonnaire. L'injection quotidienne d'HCG (1 $500 \mathrm{UI}$ ) également du $10 \mathrm{e}$ au $20^{\mathrm{e}}$ jour induit la formation de corps jaunes supplémentaires, double le niveau plasmatique de progestérone et augmente faiblement le taux de survie. Mais l'augmentation de la survie embryonnaire par la progestérone ou l'HCG n'est pas statistiquement significative $(P>0.10)$. 


\section{References}

BOYD H., REED H. C. B., 1961. Investigations into the incidents and causes of infertility in dairy cattle. Influence of some management factors affecting the semen and insemination conditions. Br. Vet. J., 117, 74.

BOYD H., 1965. Embryonic death in caftle, sheep and pigs. Vet. Bull., 35, 251-266.

ERB R. E., HOLTZ E. W., 1958. Factors associated with estimated fertilization and service efficiency of cows. J. Dairy Sci., 41, 1541-1552.

ERB R. E., GARVERICK H. A., RANDEL R. D., BROWN B. L., CALLAHAN C. J., 1976. Profiles of reproductive hormones associated with fertile and non fertile inseminations of dairy cows. Theriogenology, 5, 227-242.

GOSLING J. P., PARKER W., FOTTRELL P. F., 1975. The routine operation of a radioimmunoassay for progesterone in bovine and ovine plasma, 177-183. In PASTERNAK C. K., Rodioimmunoassay and related topics in clinical biochemistry. Hayden et Sons, U. K.

HAWK H. W., WILTBANK J. N., KIDDER H. E., CASIDA L. E., 1955. Embryonic mortality between 16 and 34 days post breeding in cows of low fertility. J. Dairy Sci., 38, 673-676.

HENRICKS D. M., LAMOND D. R., HILL J. R., DICKEY J. F., 1971. Plasma progesterone concentrations before mating and in early pregnancy in the beef heifer. J. Anim. Sci., 33, 450-454.

JOHNSON K. R., ROSS R. H., FOURT D. L., 1958. Effect of progesterone administration on reproductive efficiency. J. Anim. Sci., 17, 386-390.

KIDDER H. E., BLACK W. G., WILTBANK J. N., ULBERG L. D., CASIDA L. E., 1954. Fertilization and embryonic death rates in cows bred to bulls of different levels of fertility. J. Dairy Sci., 37, 691-697.

LAING J. A., 1949. Infertility in cattle associated with death of ova at early stages after fertilization. J. comp. Path., 50, 97-108.

ROCHE J. F., PRENDIVILLE D. J., DAVIS W. D., 1977. Calving rate following fixed-time insemination after a 12-day progesterone treafment in dairy cows, beef cows and heifers. Vet. Rec., 101, 417-419.

SPITZER J. C., NISWENDER G. D., SEIDEL G. E. Jr., WILTBANK J. N., 1978. Fertilization and blood levels of progesterone and LH in beef heifers on a restricted energy diet. J. Anim. Sci., 46, 1071-1077.

SREENAN J. M., MULVEHILL P., 1975. The application of long- and short-term progestagen treatments for œstrous cycle control in heifers. J. Reprod. Fert., 45, 367-369.

WISHART D. F., YOUNG I., DREW S. B., 1977. Fertility of norgestomet treated dairy heifers. Vet. Rec., 100, 417-420.

WILTBANK J. N., HAWK H. W., KIDDER H. E., BLACK W. G., ULBERG L. C., CASIDA L. E., 1956. Effect of progesterone therapy on embryo survival in cows of lowered fertility. J. Dairy Sci., 39, 456-461.

WILTBANK J. N., ROTHLISBERGER J. A., ZIMMERMAN D. R., 1961. Effect of human chorionic gonadotrophin on maintenance of the corpus luteum and embryonic survival in the cow. J. Anim. Sci., 20, 827-829. 